\title{
Child-Rearing in African Christian Marriages: A Case of Isongole Ward, Ileje District, Songwe Region in Tanzania
}

\author{
Nelly Cheyo and Elia Shabani Mligo
}

\section{ABSTRACT}

The greatest mandate which God entrusted to human beings since creation is keeping and sustaining the creation. Human beings are responsible towards making the creation glorify God the creator. Another important task is to bring forth other human beings - children - who will also become responsible towards creation in their adulthood. It means that the responsibility of humanity towards creation is continuous. Children are gifts from God through marriages and have to be reared to adulthood in order for them to become fully responsible to God's creation. This article examined the perceptions of church leaders and normal Christians towards child-rearing in both African traditional and Christian settings. Being guided by Ainsworth and Bowlby's Attachment Theory, the article addressed the following questions: How is child-rearing understood and practiced in the research area? Is there any laziness in the rearing of children that hinders their proper development to adulthood? In response to these questions, a qualitative study was conducted at Isongole Ward, Ileje District, Songwe region in Tanzania. Interviews were conducted to eight research participants selected purposefully after their informed consent. Data were analyzed qualitatively to obtain themes which were the basis for the presentation and interpretation of findings. Results indicated that laziness to rear children properly was one of the major hindrances for children to realize their adulthood potentials in the future. The article suggests that to have an ethical church and ethical society, child-rearing basing on proper Christian foundation is of paramount importance.

Keywords: Attachment theory, child-rearing, child rights, child abuses, isongole ward, qualitative research.

\section{INTRODUCTION}

THE FOUNDATION OF EVERYTHING that exists is God the creator of heaven and earth. God is the Father of children and adults. Child-rearing in African Christian marriages emanates from God. The Bible says,

Then God said, let us make man in our image, after our likeness; and let them have dominion over the fish of the sea, and over the birds of the air, and over the cattle, and over all the earth, and over every creeping thing that creeps upon the earth. So, God created man in his own image, in the image of God he created him; male and female he created them. And God blessed them, and God said to them, Be fruitful and multiply, and fill the earth and subdue it; and have dominion over the fish of the sea and over the birds of the air and over every living things that moves upon the earth." (Genesis 1:2628) (RSV).
Published Online: October 14, 2021

ISSN: $2736-5514$

DOI : $10.24018 /$ theology.2021.1 5.51

N. Cheyo

Department of Theology, Teofilo Kisanji University, Mbeya Tanzania. (e-mail: cheyonelly@gmail.com)

\section{E.S. Mligo*}

Department of Theology, Teofilo Kisanji University, Mbeya Tanzania. (e-mail: eshamm2015@gmail.com)

*Corresponding Author
The Bible further says:

Behold, I have given you every plant yielding seed which is upon the face of the all the earth, and every tree with seeds in its fruits: you shall have them for food. And to every beast of the earth, and to every bird of the air, and to everything that creeps on the earth, everything that has the breath of life, I have given every green plant for food, "And it was so. And God saw everything that he had made, and behold, it was very good. And there was evening and there was morning a six day." (Genesis 1:29-31) (RSV).

The above Old Testament statement texts indicate that the good creation was entrusted to human beings to be guarded and kept. Children are among God's creation, special gifts which human beings are given as a result of their marriages. Therefore, God is the founder of everything; God is the one who provides authority to human beings to control and keep the whole creation. 
Child-rearing, in African Christian marriage, refers to the way in which children are brought up in their Christian families and being in God's hands. Jesus, the founder of Christianity is the model of child-rearing when he called children to go to him without stopping them: "Let the Little Children Come to me, and do not hinder them; for to such belongs the kingdom of heaven." (Matthew 19:14; Mark 10:14; Luke 18:16) (RSV) [1]-[3]. Following the model of Jesus attachment to children during his earthly ministry, African Christian marriages (family) can rear their children to believe effectively in God making sure that children go to church all times. Children who are reared in African Christian marriages have Christian manners adopted from the church, and from parents and guardians. Hence, childrearing in African Christian marriage is very important because human beings are given an authority from God to dominate everything; it is the duty from God. Refusing to rear children is refusing the command from God.

After God's creation, currently God's creation continues through marriage. Though we have children as a reward from God, rearing them in Christian ways is our important obligation. We are supposed to rear children in a good way to have good members in churches. Failure to do so makes the church grow for a short time and fall down later on. The main problem with the responsibility of child-rearing in most churches, including the Moravian church at Isongole ward, is the laziness of responsible people who hardly care about children as God's creation. Following this problem, it is our thesis that the rearing of children in most Christian households at Isongole Ward is shrouded in laziness of parents; and most such parents are hardly serious to eradicate it in order to rear children into a required Christian manner. The survey conducted to Ndali people at Isongole Ward indicates that if parents seriously abandoned laziness effectively, they could clearly and effectively emulate the role of the church towards children in the Ndali area. In defence of the above stated thesis the following points are discussed: a child in African traditional perspective, a child in African setting, role of the church toward children, child abuse and their causes, How to avoid child abuse, and a theological reflection on children.

\section{TheOREticAl Perspectives}

This study was guided by a theoretical perspective about the development of children. The central question in the development of children is about the way in which they develop and the influences encountering them in their development process. This study was guided by [4] Attachment Theory, a theoretical perspective prominent in early childhood education. This theory is centered on parental love to children in their stages of development. It purports that children's developmental behaviour greatly depends on their attachment and intimacy with parents or care-givers. The more attached they are, the greater they respond positively to the actions of their parents and caregivers towards them and vice versa [4]. According to [5], "Individuals are proposed to develop attachment relationship with care-givers and seek and maintain proximity to these care-givers when stressed, ill or afraid". However, according to [4], research "findings suggest that infants have a natural behavioural disposition to comply with the wishes of the principal attachment figure. This disposition emerges most clearly if the attachment figure is sensitively responsive to infant signals, whereas efforts to train and discipline the infant, instead of fostering the wished-for compliance, tend to work against it (...)." According to [6], "Through repeated interactions the child creates an affectional bond, called attachment, to his or her parents". It means that children's detachment from parental care causes to them both negative and positive effects lasting till their adulthood.

Reference [6] further states:

During adolescence the attachment system is expected to go through major transformations, which permit late adolescents and young adults to go from being recipients of care to becoming potential caregivers themselves to peers, romantic partners, and offspring. At the same time, they begin to function all the more independently of their parents and gradually transfer dependencies from parents to peers and romantic partners, who by late adolescence for some people begin to function as full-blown attachment figures. (...). The kinds of attachment relationships that people form in adulthood share basic similarities with those observed in infancy and early childhood. More specifically, adults show a desire for proximity to the attachment figure when stressed, increased comfort in the presence of the attachment figure, anxiety when the attachment figure is inaccessible. (...). Throughout life, attachment behaviours are especially evident when an individual is distressed, ill, afraid, or reunited with an attachment figure after a long absence.

One of the major weaknesses of this theoretical perspective is that it hardly addresses the genetic origins of human traits. This weakness has led most scholars of human developmental psychology to focus on what is called the "Five Factor Model" which "has traditionally emphasized genetic origins of personality structures" [6]. However, this theoretical perspective is important in child-rearing because it clearly demonstrates the role of affectional bond of parents and care-givers in moulding the development behaviour of children. In this article, Attachment Theory will be of help to interpret experiences of research participants on their experiences of child-rearing at Isongole Ward, Ileje District, Songwe region in Tanzania.

\section{Methodological Perspectives}

The discussion of above-stated points of this study benefited from new ideas obtained from the understanding of normal Christians and church leaders within Isongole Ward in the Moravian church in Tanzania, Southern province (MCT-SP). A study was conducted between April and May 2021. Six participants, selected purposefully, were involved in the study. Employing Interpretivist research philosophy and qualitative approach, the study sought to investigate the various experiences of participants on issues referring to the way child-rearing is done among the Ndali people of Isongole Ward, and the way in which participants 
attached meanings to those experiences [7]-[9]. Appointments were made with each participant and in-depth semi-structured open-ended interviews were conducted to each of them after each one's informed consent. Reference [10] asserts that: "The voluntary consent of the human subject is absolutely essential. This means that the person involved should have legal capacity to give consent; should be so situated as to be able to exercise free power of choice, without the intervention of any element of force, fraud, deceit, duress, over-reaching, or other ulterior form of constraint or coercion; and should have sufficient knowledge and comprehension of the elements of the subject matter involved as to enable him to make an understanding and enlightened decision". Since research was conducted to adult people of above twenty-five years old, informed consent was obtained after participants were told about the objectives of research, duration of our research, the methods to be used, the possible risks due to their participation, issues of confidentiality and anonymity, and their right to withdraw from participation in the research at any time. The collected research information was organized, and analysed qualitatively to obtain themes, which are the sole components for presentation and discussion in this article.

\section{A child in African Traditional Perspective}

This section discusses child-rearing according to African traditional perspective. Participants were asked about the way children were reared in African traditional setting in the Ndali community at Isongole Ward. According to research participant A,

Child-rearing in African traditional perspective refers to the way in which a child is reared in its family. In traditional perspective, the child must be under the family, it must be under the mother and father. Children's rearing in African Traditional perspective is looked negatively because of culture; in African traditional, perspective about marriage, the mother is the big character. If any problem occurs in marriage, it is defined that the mother is the source of the problem even though the problem comes from the father. We see this in the family of $T$ and $A$ which had no child for a long time. When they go to the hospital was seen that the problem was on the side of father. Looking negatively is not good because God is the creator of everything; even in traditional perspective we believe that God is the savior in our life. The union of father and mother has a product, which is the child; and childrearing in African traditional perspective is done in order to develop a good generation in God and society. Child-rearing in Africa traditional perceptive has its focus on helping the child to grow in traditional way and which is required by society. The African traditional perspective focuses on having a good and well-reared child; if the child does not follow the instructions provided, her mother or father becomes angry because he/she loses the culture; a thing which is not required. (Personal communication, April 4, 2021).
A similar statement is made by [11] about the role of the father to his family: "Children understand the concept of God better if they understand their earthly or physical father. The father has to demonstrate a godly character. He has to be a follower of Christ and must reveal certain characteristics, such as humbleness, softness of heart and patience towards his children according to 2 Tm 2". We agree with participant A's and Freeks' statements above; we believe that the mother is the secretary (the executive) of the African family and the father is the head of that family, and each of them plays a specific role towards the nurture of children. If the secretary or the head of the family is not punctual, it is a problem [12].

Among the Maasai, for example, the roles between parents are quite clear:

The Maasai train children, at a young age, on responsibility. Boys and girls from the age of four start to undergo training in herding lambs, checking out warts or bugs, basic milking and feeding the lambs; and eventually graduate to taking care of 8 mature cattle. For the boys, these trainings are usually done by the young Moran, or a warrior, while young girls are taught by their mothers and grandmothers. Young girls learn house chores, fetching water from the river, collecting firewood and cooking [13]-[14].

Therefore, child-rearing in African traditional perspective must be done by the two couples, the mother and the father to make a good family and build a good society. Laziness is not something entertained in the rearing process; each of the parents has to work hard in providing instructions to the born child.

Moreover, research participant B, providing a bad example of rearing, argued that "youths, especially females becoming pregnant at homes is the shame of the whole society. In African traditional perspective, a child cannot be a good child if it does not follow the African culture of the respective area. If it follows the foreign culture, for example, of wearing styles, coping bad behaviours from friends who practice drug abuse, beer drinking, cigarette smoking, sexual promiscuity found in mass media like radio, phones, and magazines, is likely to be lost" (personal communication, 13 April 2021). Hence, it is true as participant $\mathbf{B}$ says that the child copying many things from different cultures bores the family and society at large. In order for children not to copy bad behaviours, both parents in the African setting have to abandon laziness in rearing their children in the required African traditional manners. It means that parents themselves should not have a bad behaviour.

Bad behaviour of children also emanates from parents/guardians themselves. This view was reiterated by most participants in the interview sessions. For example, participant C said that "parents with bad behaviour, for example drinkers, cigarette smokers, and bad-tempered parents can lead the child to copying from its parents entering into a bad condition" (personal communication, 17 April 2021). According to participant C, child-rearing in African traditional marriages must be done carefully to have a good generation. A child in African Christian perspective 
is very important to have good members in church and develop the generation believing in God, Child-rearing in Africa traditional perspective also helps to build a good society because members of the church are also members of society; both of these two groups go together. Hence, parents are supposed to change their behaviour in order for them to produce a good generation in the family and society as a whole. Parents' behaviours symbolize the culture in which children have to grow.

With similar sentiments, participant $\mathbf{D}$ also stated that, " $A$ child in African traditional perspective must be in strong norms and wisdom introduced by the elderly people; norms are rules and principles which protect the culture of a certain place. Children reared in African traditional culture are expected to behave much in traditional way because of norms present in that society" (Personal communication, 17 April 2021). Therefore, through descent rearing of children the society obtains descent traditional leaders and citizens of society.

\section{A CHILD IN CHRISTIAN PERSPECTIVE}

This section focuses on child-rearing from a Christian perspective. In this theme, most participants showed concern for the church as an organ of God to show great concern for children as anticipated church members of tomorrow. Participant $\mathbf{E}$ argued that "Since we know that children start to be cared for within the wombs of their mothers it is in this time when the mother requires to eat a good food which helps to protect the child making it comfortable when is in the womb of the mother. Similarly, the child will tend to behave in good manners when in Christianity. It is expected to adapt Christian behaviours and customs from its parents. This is what it means that the beginning of church is home" (personal communication, April 28, 2021).

According to participant E, a child brought up in a Christian marriage is expected to behave in the same way as their parents behave. The child is expected to think positively on Christian faith, that God is there and is its savior. The character toward society is also expected to be good because the child practices what elder Christians practice. It will fear evil, several abuses, drug abuses, and stealing other people's properties; it will interact sympathetically with friends and parents. It will be very humble and attentive to elders and do things by reasoning. Furthermore, it will respect itself and its elders and avoid engaging in traditional healing, treatments which have not undergone any experiments or tests from professional doctors [15], [16]. What participant $\mathbf{E}$ emphasizes in the above quotation is that children should be cared for by any means through allowing Christian faith to be imparted to them from one stage of inheritance to another. Christian rearing is very important and requires being taken seriously by Christian parents. Recklessness in rearing children following Christian ethos is the source of having immoral society and immoral church.

Why should there be no laziness to parents in rearing children to adhere to Christian ways? A simple answer is that they require discipline as members of the church and society. However, participant $\mathbf{E}$ referring to the Bible explained that "in Proverbs 29:17, the word of God says:
'Discipline your son and he will give you rest; he will give delight to your heart'" (Personal communication 26 April 2021). However, the question of disciplining the child is a hard work; it takes the fruit of the spirit which "are love, joy, peace, patience, kindness, goodness, faithfulness. Gentleness, self-control against such there is no law." (Galatians 5:22) Parents who really love their kids will discipline them as God does with us (Hebrew 12:7-11). According to Esther, it is for discipline that one has to know that God is treating us as sons and daughters. Besides this God we have earthly fathers to discipline us; and we respect them. However, they discipline us for a short time at their pleasure; but God disciplines us for our good, that we may share God's holiness. For the moment, all discipline seems painful rather than pleasant; later it yields the peaceful fruit of righteousness to those who have been trained by it. Hence, we agree with Esther because her opinion about discipline for children is very crucial; it emulates the way the Bible teaches about discipline. Esther's words awaken lazy parents to see the importance of rearing children in a well discipline Christian way to enable them avoid the vulnerability to various worldly temptations.

Participant $\mathbf{F}$ had similar sentiments when stated that,

children are vulnerable to suffering even in good circumstances but when there is poverty or violence, kids can suffer real damage. God asks people who worship him to help take care of kids in such vulnerable places Christian perspective children are to be taken care is to care by the farther and the mother, The problem is that nowadays the child has the mother and the farther for a short time, even in Christian marriages. Most fathers and mothers are not living in the same places because of conflict in marriages. In fact, this is not child-rearing according to African perspective. The child is left to live with the grandfather and grandmother. At the same time, the grandfather and grandmother have no enough power for controlling the child. Obviously, the product is to join with bad groups which are not of Christian perspective. And also, we can see that in our environment areas found street children or children in hard environment. (Personal communication, 30 April 2021)

According to research participant $\mathbf{F}$ above, this condition is caused by parents who separate. Separation between parents affects the well-being of children [17]. Hence, it is important to keep marriages for the sake of the gift of children which God provides upon couples after weddings.

The Bible provides a role model which parents ought to live in order to be emulated by their children. The Bible, in Ephesians 5:21-29 (RSV), says:

Be subjected to one another out of reverence for Christ. Wives are subjected to your husbands as to the Lord. For the husband is the head of the wife as Christ is the head of the church his body and is he saviour. As the church is subjected to Christ, So let wives also be subjected in everything to their husbands. Husbands love your wives, as Christ loved the church and gave him himself up for her, that the might sanctify her, 
having cleansed her by the washing of water with the word, that he might present the church to himself in splendour, without sport or wrinkle or any such things, that she might holy and without blemish. Even so husbands should love their wives as their own bodies. He who loves his wife loves himself. For no man ever hates his own flesh, but nourishes and charities it, as the Christ does to the church.

Consequently, this way of relationship between parents becomes a good example to children. The Bible talks the truth about husband and wives living together with peace, which is the product of love. Love cannot count any kind of bad behaviour from another. It endures all for the glory of God.

\section{Child Rights in African Christian Setting}

Vailaau (n.d.:6) reports that,

In 1993, New Zealand and 192 other countries signed a United Nations convention that says '...the child, for the full and harmonious development of his or her personality, should grow up in a family environment, in an atmosphere of happiness, love and understanding.' The United Nations Convention on the Rights of the Child (UNCROC) is the most widely accepted human rights treaty ever. It states that children should be protected 'from all forms of physical or mental violence, injury or abuse, neglect or negligent treatment, maltreatment or exploitation, including sexual abuse, while in the care of parent(s), legal guardians or any other person who has the care of the child' [18].

This section discusses child rights in African Christian setting. To our opinion this process has to start soon after children are born. After they are born, parents require making sure that they grow in a spiritual way. Children have to be well-reared when are still young. According to child rights, in African setting children also have to be educated. Education starts in the family; if the family is living the life of Christ, children will be Christians; if the family lives a pagan life and children will also be pagans. This explanation shows that there is paganism in the church while people pretend to be Christians. Segregation of children prevalent among families cannot show children their rights in African Christian settings. Surveys conducted among Ndali people from Isongole indicated this segregative attitude clearly. Therefore, Christians are supposed to be careful when living Christian lives in attachment with their children. Christians require living concrete Christian lives while observing the rights of children as they grow under their custody. One such important right for children is to be reared according to the Christian discipline throughout their lives.

Another important child right is providing equal rights or opportunities to children of males and female sexes. Research participant $\mathbf{G}$ introduced that "child right in African Christian marriage is that children have two sexes-males and females. Male children have greater chances and opportunities in families than females. During domestic works, one may see that males do not participate well; all domestic works are done by females. He becomes a farther while still young and the female becomes a mother while still younger" (Personal communication, 28 April 2021). The segregating situation stated by the aboveresearch participant was quite vivid in a survey conduct among Ndali people at Isongole. To our opinion, gender segregation between children is not a right thing in African Christian setting because no one child between them was born for the other; all works should be shared without segregation. It means that children should grow with the attitude of equality in terms of gender roles.

Another child right in the African Christian setting is based on rearing children in a Christian way both at home and outside the home. Research participant $\mathbf{B}$ had the following views:

One may see that some children, especially those studying in different schools and colleges, are good Christians when at home and outside the home live as pagans. This situation happens because children have the right to have education and religious teachings at school but hardly obtain them. At schools or colleges, there are Christian children requiring to be taught Christian education. However, because of the lack of pastors or professionals in Christian education, children are not taught. The church seems to concentrate more on teaching elders than children in different schools and colleges. For example, the Moravian church in the Southern Province, Western district, has a considerable shortage of pastors who can help children spiritually. Leaders of the province send pastors in different areas, but not in schools and colleges. This way of handling children in schools and colleges within the district is hardly compatible with child rights in African Christian setting. Obviously, doing that is segregation because leaders know fairly well that congregations are for all groups of people. Baptizing children is the right in African Christian setting. When baptizing children, we remove all evil spirits from them and make them pure and safe in God. Baptizing them alone hardly makes the church fulfil God's command to make people disciples. Teaching them is another obligation. Children have the right to have education and religious teachings according to their ages, from Sunday school till adulthood. (Personal communication, 22 May 2021).

We agree with the opinions of research participant $\mathbf{B}$ above, especially when looking at what prevails in the Southern Province (Rungwe); where there are many secondary schools having a few pastors for teaching Christian education. Children require having pastors but fail to attain them. To our opinion, the lack of pastors to teach children in secondary schools in the Western district is caused by irresponsible leadership in the church that hardly considers the future of the church. Irresponsible leadership makes the church irresponsible towards child-rearing, especially those in schools and colleges, leading to ethically irresponsible Christians in the future. 


\section{Child Abuses And Their CAuses}

Apart from the rights stated above, there are times when children are abused in one way or another. This part explains what it means by child abuse and the possible causes of it in the research area. According to research participant $\mathbf{D}$, "Child abuse is the situation conducted by a person or people to a child who haven't any kind of basic requirements. The notable character of abuses is seen among orphans and poor families. An orphan is the child whose mother and father have passed away, or one parent passed away, and child abuse comes after that action" (Personal communication, 15 May 2021). Research participant $\mathbf{D}$ further emphasized:

Child abuse is a big problem in our community because the community is faced by this problem. Not only that, but also parents who separated from marriage, their children are abused by the family rearing them. Moreover, child abuse comes to the child who is not having a good manner, discipline and unfaithfulness general: it means that the behaviour of the person is negatively changing and is abused because of that behaviour. Sometimes, the abuse of children causes the change of their behaviour. (Personal communication, 15 May 2021)

Therefore, what research participant $\mathbf{D}$ says is that child abuse hardly helps build good behaviour of the children, but worse.

The question is: What causes abuse to children, and how is it done? Causes of child abuse are many and can be executed in different ways. In the research area, for example, research participant $\mathbf{F}$ introduced the causes and execution of child abuse saying that "Isolation and lack of support is among child abuses in the family, friends or community. Low self-confident-parents may doubt the ability to meet their children's requirements and find it hard asking for help. Problems of addictions to alcohol may affect parents' ability to meet their children's requirements. Past childhood experienced of parents may also be another cause-parents may have experienced abuse as children in their own families, which can have caused them to develop a bad behaviour in their lives" (Personal communication 11 May2012). Thus, as just said in this paragraph, child abuse is not a source of achievement; rather, it is the source of deterioration of morality and disrespect of human rights.

Another cause of child abuse is parents' or guardians' neglect to provide basic requirements such as food, shelter, and clothes. Food is a basic requirement in the life of all living things. Failure to have adequate food causes many problems to occur to human beings, such as diseases, because most diseases can easily be treated by just eating enough and adequate food [19]-[22]. Reference [20], for example, assert that "Child development theory suggests that children have specific stage-salient developmental needs that, if unmet, hinder successful adaptation within and between developmental stages." Therefore, neglect to provide food to children is physical and psychological torture that greatly hinders their descent development. Apart from food, children require clothes in order to protect themselves from winter or from being looked at by someone; children require protecting their bodies as adults do. It is the responsibility of parents and guardians to provide children with clothes to protect their bodies; failure to fulfil that responsibility exerts torture upon children.

Lack of knowledge or ignorance is another great cause of abusing children. Parents/guardians entering in marriage without seminars about marriage and family life mostly do things or conduct life with ignorance. They hardly know how to care for children at different times. Such marriages have no skills and children grow only by the grace of God. For the best rearing of children, it is our contention that parents should attend different seminars to add knowledge on child-rearing and family life as a whole.

\section{How to AvoId CHILd ABUSE}

The most important question in this part is about the ways in which child abuses can be avoided. Research participants had varied responses to this question. However, this part summaries the views of research participants into the following activities as possible means. First, teaching children their right way as the Bible admonishes (Proverbs $4: 13$ ). When children are taught their right way, they will know how to be safe from being abused by playing their roles towards parents and other elders in society.

Second, parents and community at large should know what child abuse really is. The knowledge of child abuse will make it easier for them to handle their children in diverse situations. Physical and sexual abuses are clearly constituents of child maltreatment which require being avoided through parents' and society members' knowledge [23]-[26]. Therefore, knowledge is a powerful tool towards the eradication of child abuses that can lead to their developmental effects.

Third, parents should examine their behaviour. Through education, they should know that abuse is; they should know that abuse is not only physical, but also words and actions which can inflict deeply and cause lasting wounds. Therefore, in order to mitigate or avoid child abuse, research participants proposed the following course of actions for parents/guardians to their children:

\section{A. Show Parental Love}

Love from parents is one of the most essential aspects in child-rearing. Some children fail to obtain love from parents because of their own bad behaviors; for example, a female child can lack real love from parents because of not hearing and respecting what parents say [27], [28]. Moreover, they can lack love from their parents because of unnecessary disagreements with parents in some issues. They can decide to do things which parents and society do not endorse such as being prostitutes and thieves. Therefore, children have to obey parents and grow according to their instructions in order to mitigate possible abuses from them.

\section{B. Avoid Child Labour}

There are so many issues of child labour in current society. Sometimes, child labour can be found even in families. One can find the child being reared by another 
child [29], [30]. For example, the child from the village may come to town to do the work of rearing children, with a very small salary. Such kind of work is child abuse. Therefore, every family requires having a good plan of life to avoid unnecessary child abuses. Effective plans and avoiding laziness within families may reduce child abuses to the great extent.

\section{Avoid Child Violence}

Child violence takes place in many societies in African Christian marriage. The Unicef/Inter-parliamentary Union [31] document states: "Extreme forms of violence against children-including sexual exploitation and trafficking, female genital mutilation/cutting, the worst forms of child labour and the impact of armed conflict - have provoked international outcry and achieved a consensus of condemnation, although there is still no rapid remedy". Violence against children in households, schools, workplaces, etc., is prevalent. In the research area, for example, Salome (not her real name), a Ndali child destroyed the vessel in the family; her mother took time to beat her heavily and Salome died due to severe beating. This kind of punishment indicates the most heavily executed abuses towards children in their daily upbringings. Hence, rearing children in Christian faith and encouraging them going to church helps them have good habits and fear of God in their Christian life.

Violence against children is not only physical, but also psychological and emotional. Prohibiting children from going to church, which most parents do, is psychological and emotional abuse [32]. Therefore, it is not good for a child to live without going to church and is not good to be lazy in rearing children in Christian ways because children are anticipated leaders of the church and society of tomorrow.

\section{Avoid Early Marriage}

Reference [33] writes: "While early marriage takes many different forms and has various causes, one issue is paramount. Whether it happens to a girl or a boy, early marriage is a violation of human rights". Early marriages are violations of human rights because they mostly appear without any preparation and at tender ages where children are not provided with free and full consent to engage into such marital relationships. When they bear children, especially girls, some parents directly think of them as sources of profit. They decide to find men who are aged to marry those younger girls without any desire or consent of girls themselves; and because parents of both sides have agreed, the actions normally take place. This way of engaging children in marriage is child abuse causing greater physical, psychological, and emotional harms to respective children. For example, at the research area, Luse (not her real name) who was a younger girl married Clement (not his real name) without agreement. Their marriage ended in frustrations and divorce. Therefore, child abuse is not required because is a bad action. As clearly noted, whenever they happen, forced marriages are some major abuses to girls and boys in most societies, including that of the Ndali in Songwe region in Tanzania.

\section{Role OF THE CHURCH TOWARDS CHILDREN}

The church and its various organs require playing a key role in children's rearing. According to [34], "The role of churches in relation to children is to promote a society in which every child is valued, and all children have the opportunity 'to grow up as competent and confident learners and communicators, healthy in mind, body, and spirit, secure in their sense of belonging and in the knowledge that they make a valued contribution to the society" [34]. Churches can implement this role through rehabilitating Christians' homes. Emphasizing this role, research participant D states that, "The first school in the whole world is from the family. I believe that children are our future. Teach them well and let them lead the beast way. Show them all beauty they are required to have. Let children live in happiness and remain as we used to be like" (Personal communication, 03 May 2021). The words of research participant D remind parents that in African Christian context, the family should be the first school institution where children learn through, oral tradition and actual practices.

As a school, education is passed through stories and real actions from parents and guardians. The history of the clan tribes is narrated through stories by parents or elder sisters/brothers to their young ones. This is done in the evening around the fireplace while waiting for their supper. The early education is sometimes called an informal or family education. Family education has, in a great extent, been affected by social changes in communities. Formal education has dominated the informal education which unfortunately is not valued as it was before. Younger people go to boarding schools where they spend a long time every year. They are rarely exposed to informal education. However, we have to revive the importance of family education, where the parent has to be seen as holding a very important responsibility. In this way our children will be having a proper informal education in every family. For example, if the family has one child, and decides to send him/her to boarding school, that child will attain formal education. However, grandmothers of that child will not be happy for their grandmother because is still young to live without parents in the boarding school. Therefore, the first institute for children's education is the family, and then sending them to boarding school. But that practice of sending children to boarding schools is hardly good according to African perspective because it brings problems to children, for example making them lack respect, developing laziness and having a moral decay.

In addition, research participant $\mathbf{D}$ stated that, "Some people say that at home is where the church begins. Parents should send their children to Sunday school to be exposed to the word of God. Well-trained Sunday school teachers are required in congregation to teach children the right gospel of Jesus. It means that the main role of the church towards children is teaching them the word of God. The church is a teaching body of Christ as Jesus himself spent most of his time teaching people through words and deeds" (Personal communication, 03 May 2021). Therefore, following Participant D's above statement, the church is obliged to ensure that the Christian mentality dwells among people in society. As Naseri (2014:44) emphasizes, "It is the mission 
of the Church to educate and to ensure strong [Christian] character formation." [35], [36].

Unfortunately, [37] says, "It is sad but true that a child may attend Sunday school and church faithfully for years and not hear the simple gospel. Hence, very few children experience the gospel. Most of them think that one can be saved by being good, or by being baptized or by joining the church. Our purpose in advocating the gospel to children is to show them that they require a Savior and that the Lord Jesus is the very Savior they require. And then we must encourage the child to receive that Savior". Mambo's statement insists that recklessness and irresponsibility on the part of churches should not be tolerated since children hold an important position in the development of the church of God.

Moreover, the Bible say in (Ephesians 6:1-4) that "Children, obey your parents in the Lord, for this is right. 'Honour your father and mother' (this is the first commandment with a promise), 'that it may be well with you and that you may live long on the earth.' Fathers, do not provoke your children to anger, but bring them up in the discipline and instruction of the Lord." Following this text, parents require keeping their children spiritually and physically to control the new generation in society. Furthermore, participant $\mathbf{C}$ quoted the Bible saying that, "Parents, do not treat your children in such a way as to make them angry; instead, bring them up with Christian discipline and instruction." (Ephesians 6:4) (Personal communication, 11 May 2021) This biblical text cements on the way children should be handled regarding the existing religious and social conventions for them to become descent members of the church and society.

Another role of the church toward children is to emphasize them believe more in God. The church has a Christian identity as a believing people; children, as members of the Church, should be directed towards believing in God not in gods because God is the one who controls each and everything on the earth's surface. If one teaches children, they care too much about the provided teachings. For example, one may tell them that if are willing to do evil that is outside God and will be punished by God. Children will be afraid to do evil and continue finding holiness in their lives. Hence, educating children about good things is the responsibility of the church as a community of believers.

Churches can do roles of educating children through different ways apart from going to Sunday school. The thing which is opposite to the will of God is excessive drinking of alcohol and nasty words to others. Therefore, educating children is the preparation for the church. It is not a wasting of time. It is building the body of Christ, not destroying it. Furthermore, it is something the church should concentrate for the future of the Church.

\section{Theological Reflection on Child-Rearing}

If laziness and irresponsibility in rearing children is one of the major causes of moral degradation and child abuses, what does God say about children? This question is of focus in this part. Research participant $\mathbf{E}$ stated, "We Christians are followers of Christ because all share the belief that
Jesus Christ is our saviour. He died for us to join us to God" (Personal communication 20 May 2021). Theologically, we know that children are obtained from marriage; and the source of marriage is God, when God create Adam and Eve in the Garden of Eden. Genesis 4:1-7 says that "Now Adam knew Eve his wife and she conceived and bore Cain, saying, 'I have gotten a man with the help of LORD. And again, she bore his brother Abel." Since God is the source of children. We are supposed to rear them in our marriages to have good future Christians; for example, sending them to Sunday schools to have education is where the church begins. Parents should send their children to Sunday schools to learn the word of God. Moreover, welltrained Sunday school teachers are required in congregations to educate children properly.

Another theological conception on children is that they are the gift from the Lord and are a real blessing [38], [39]. The sons a man has when he is young are like sword in a soldier's hand. Happy is the man who has many such arrows. He will never be defeated when meets his enemies in the place of judgment. Children and parent require living in good relationship. Children should show reverence to their parents and parents should respect and care for their children. Hence, the Bible teaches so many teachings on child-rearing in African Christian marriages. We expect to have good parents and good Christians in all generations through listening to what God teaches. Good Christians must be built upon good foundations from the Bible for children to benefit from the Lord God, who is the creator of heaven and earth and all things found inside it.

\section{CONCLUSION}

In this work a survey was made to determine the understanding of normal Christians and church leaders about child-rearing within the MCT Southern Province, mainly basing on Isongole ward. Aspects discussed include a child as understood in the Africa traditional perspective, a child in Christian perspective, child rights in African Christian marriages, child abuses and their causes, how to avoid child abuses and a theological reflection on children. Laziness among parents and guardians in rearing children was the problem of concern in this work. We defended the thesis that child-rearing in African Christian marriages among most parents at Isongole ward was shrouded in laziness and irresponsibility and parents were hardly serious to eradicate it. Following the discussion of various perceptions of research participants in this work regarding the above-stated thesis, we recommend that parents should commit themselves fully in rearing children to the required Christian manner. The secrete issue regarding rearing children is to sacrifice them to God by bringing them to church and baptizing them; baptizing is a symbol of growing in God to protect them. After baptizing them, the church requires providing effective teachings about the descent way of the Lord. Any kind of laziness in rearing children should have a zero tolerance in order for children to grow with a good moral foundation. 


\section{ACKNOWLEDGMENT}

This article is the result of research conducted among the Ndali people in Songwe Region Tanzania. Authors are grateful for the contributions made by all research participants. Moreover, researchers appreciate the contributions of First Year Bachelor of Divinity degree students $(2020 / 2021)$ at Teofilo Kisanji University for the various discussions held in class regarding the course of African Christian Marriage, and the concept of "ChildRearing" in particular. Their contributions were invaluable

\section{REFERENCES}

[1] D. Reistroffer, "Let the Little Children Come to Me. 'Don't Stop Them,"' Journal of Family Ministry, 13 pp. 31-35, 1999.

[2] C. Myers, "As a Child: Jesus' Solidarity with the Least of the Least". Living Pulpit, 12(4): 18-19, 2003.

[3] O.M. Bakke, "Upbringing of Children in the Early Church" Studia Theologica - Nordic Journal of Theology, 60(2): 145-163, 2006.

[4] M.D.S. Ainsworth and J. Bowlby, "An Ethological Approach to Personality Development." American Psychologist, 46, 331341,1991

[5] E. Scharfe "Attachment Theory," Encyclopedia of Evolutionary Psychological Science, 2017.

[6] M. Fransson. "Attachment and the Development of Personality and Social Functioning," Uppsala: Acta Universitatis Uppsaliensis, Sweden, 2014.

[7] J. Wilson, "Essentials of Business Research: A Guide to Doing your Research Project," Thousand Oaks, CA: Sage, 2014.

[8] P. Corbetta, "Social Research: Theory, methods and techniques," Thousand Oaks, CA: Sage, 2003.

[9] M. Denscombe, "The Good Research Guide: For Small-Scale Research Projects," Fourth Edition. New York, NY: McGraw Hill, 2010.

[10] S. Loue, "Textbook of research ethics: Theory and practice," New York, NY: Kluwer Academic, 2002.

[11] F.E. Freeks, "Christian Fathers as Role Models of the Church's Fulfillment of the Missio Dei in a Fatherless Society," Missionalia, 46(3): 331-354. 2018.

[12] S.A. De Roos, J. Iedema and S. Miedema "Influence of Maternal Denomination, God Concepts, and Child-Rearing Practices on Young Children's God Concepts." Journal for the Scientific Study of Religion, 43(4): 519-535, 2004.

[13] Parenting in Africa Network., "Reflections on Africa's Indigenous knowledge on parenting: Indigenous parenting practices of different communities in Africa." Gold Rock Park, Mombasa: Parenting in Africa Network, 2014.

[14] A. Murovhi, P. Matshidze, V. Netshandama and E. Klu, "Traditional Child Rearing Practices in Vhavenda Families South Africa." Journal of Gender, Information and Development in Africa, 7(1): 21-37. 2018.

[15] M.R. Petro, E. G. Rich, C. Erasmus, and N. V. Roman, "The effect of religion on parenting in order to guide parents in the way they parent: a systematic review." Journal of Spirituality in Mental Health, 20(2): 114-139, 2017.

[16] J.C. Schreiber, "Parenting, Policies, and Practice: Christian Influence on Child Welfare in America." Social Work \& Christianity, 38(2): 293-314, 2011.

[17] K.P. Pratt, "Divorce's Effect on Children: How the Church can bring about Healing." Christian Education Journal, 6(2): 34-41, 1985.

[18] N. Vailaau, "Theology of Children." Wellington: Barnardos, 2005.

[19] D. DePanfilis, "Child Neglect: A Guide for Prevention, Assessment, and Intervention." U.S. Department of Health and Human Services Administration for Children and Families. Office on Child Abuse and Neglect, 2006.

[20] D.J. English, R. Thompson, J.C. Graham and E.C. Briggs, "Toward a Definition of Neglect in Young Children." Child Maltreatment, 10(2): 190-206, 2005.

[21] D. Turney and K. Tanner "Working with neglected children and their families." Journal of Social Work Practice, 15(2): 193-204, 2010.

[22] C. Herruzo, A.R. Trenas, M.J. Pino and J. Herruzo, "Study of the Diffferential Consequences of Neglect and Poverty on Adaptive and Maladaptive Behavior in Children." International Journal of Environmental Research and Public Health, 17(739):1-12, 2020.
[23] M.J. Ezekiel, F. Kisanga, I. H. Mosha, A. Anaeli, S. R. Kamazima, R. Mpembeni, and E. P. Muhondwa, "Factors associated with child sexual abuse in Tanzania: a qualitative study," Tanzania Journal of Health Research, 19(2): 1-10, 2017.

[24] K. Lalor, "Child sexual abuse in Tanzania and Kenya," Child Abuse \& Neglect, 28, 833-844, 2004.

[25] S.L.B. Mikhail, "Child Marriage and Child Prostitution: Two Forms of Sexual Exploitation," Gender and Development, 10, 43-49, 2002.

[26] F. Kisanga, "Child sexual abuse in urban Tanzania: Possibilities and barriers for prevention," Umeå University, Umeå, Sweden, 2012.

[27] K. Määttä and S. Uusiautti, "Parental Love - Irreplaceable for Children's Well-Being," Global Journal of Human Social Science Arts \& Humanities, 12(10): 1-8, 2012.

[28] F. Cline and J. Fay, "Parenting with Love and Logic: Teaching Children Responsibility," Colorado Springs, CO: NavPress, 2006.

[29] J.C. Andvig, "Child labour in sub-saharan africa - an exploration," Forum for Development Studies, 25(2): 327-362, 1998.

[30] J. Sumberg and R.S. Wheeler, "Children's work in African agriculture: Time for a rethink.” Outlook on Agriculture, 49(2): 99102,2020 .

[31] Unicef/Inter-parliamentary Union, "Eliminating Violence against Children," Handbook for Parliamentarians, 13, 2007.

[32] Better Care Network, "Violence against Children and Care in Africa: A Discussion Paper," New York, 2017.

[33] C. Spouses, "Early Marriage," Innocent Digest No. 7, Unicef, Florence Italy, par. 4, 2001.

[34] N. Vailaau, “A Theology of Children," Wellington: Barnardos, 2005.

[35] C.N. Naseri, "The Church, Parents and Teachers as Moral Educators of Children.” Koinonia, 6(4): 41-54, 2014.

[36] T. Georgina, "A Reflection on the Role of the Church in Child Development in Ghana: A Case Study of Atonsu District Assemblies of God, Ghana." International Journal of Academic Research and Reflection, 8(3): 28-48, 2020.

[37] A.W. Mambo, "Understanding Developmental Characteristics of a Child in Christian Faith among Sunday-School Children in Kenya." IRA International Journal of Education and Multidisciplinary Studies, 14(3): 54-66, 2019.

[38] K. Mulzac, "Hannah: The Receiver and Giver of a Great Gift." Andrews University Semimry Studies, 40(2): 207-217, 2002.

[39] I. Marey-Sarwan, H. Otto, D. Roer-Strier and H. Keller, "Parenting among the Arab Bedouins in the Naqab Desert in Israel," 105-123, 2015 .

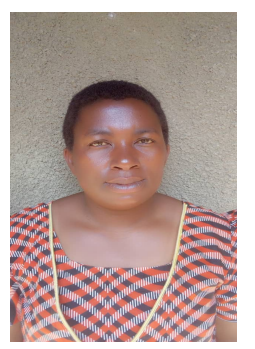

Nelly Cheyo was born on $2^{\text {nd }}$ May 1997 at Ikinga village, Ileje District, Songwe Region in Tanzania. She received her Certificate in Theology from Lutengano Theological College in 2013, and her Diploma in Theology from Lutengano Theological College in 2019.

She worked as a Pastor and Street Evangelist at Isongole Street of the Moravian Church in Tanzania Southern Province from 2015 to 2018. From November 2020, she joined Teofilo Kisanji University as a student in the Bachelor of Divinity Degree Programme.

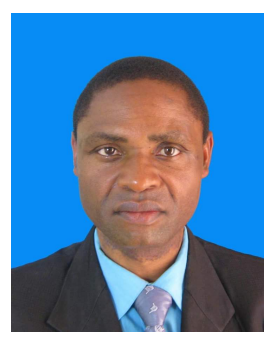

Elia Shabani Mligo was born on 23rd June 1969 at Mayale Village, Wanging'ombe District, Njombe Region in Tanzania. He received his Bachelor of Divinity degree (1999) from Tumaini University in Arusha Tanzania, a Master of Philosophy in Contextual Theology (2004) and Philosophiae Doctor in Contextual Theology (2009) both from the University of Oslo in Norway.

His areas of interest are Contextual Theology and Social Science Research. After his Doctoral studies, he worked as Lecturer of Contextual Theology and Social Science Research at various institutions in Tanzania, including Kidugala Lutheran Seminary in Njombe, Amani Centre of the University of Iringa, and Mbeya Centre of Tumaini University Makumira. Currently, he is Associate Professor of Contextual Theology and Research at Teofilo Kisanji University in Mbeya Tanzania.

Prof. Mligo has published extensively in areas of Contextual Theology and Research. His currently published books include, but not limited to, the following: Tanzania's Development Goals towards Industrial Economy (Gredo, 2021), Women within Religions: Patriarchy, Feminism and the Role of Women in Selected World Religions (Eugene, OR: Wipf and Stock/Resource, 2020), Rediscovering Jesus in Our Places: Contextual Theology and Its Relevance to Contemporary Africa (Eugene, OR: Wipf 
European Journal of Theology and Philosophy www.ej-theology.org

and Stock/Resource, 2020), Writing Effective Course Assignments: A Guide to Non-Degree and Undergraduate Students (Eugene, OR: Wipf and Stock/Resource, 2016) and Introduction to Research Methods and Report Writing: A Practical Guide for Students and Researchers in Social Sciences and the Humanities (Eugene, OR: Wipf and Stock/Resource, 2016). 